\title{
Reproductive behavior, development and eye regression in the cave armored catfish, Ancistrus cryptophthalmus Reis, 1987 (Siluriformes: Loricariidae), breed in laboratory
}

\author{
Sandro Secutti and Eleonora Trajano
}

\begin{abstract}
The troglobitic armored catfish, Ancistrus cryptophthalmus (Loricariidae, Ancistrinae) is known from four caves in the São Domingos karst area, upper rio Tocantins basin, Central Brazil. These populations differ in general body shape and degree of reduction of eyes and of pigmentation. The small Passa Três population (around 1,000 individuals) presents the most reduced eyes, which are not externally visible in adults. A small group of Passa Três catfish, one male and three females, reproduced spontaneously thrice in laboratory, at the end of summertime in 2000, 2003 and 2004. Herein we describe the reproductive behavior during the 2003 event, as well as the early development of the 2003 and 2004 offsprings, with focus on body growth and ontogenetic regression of eyes. The parental care by the male, which includes defense of the rock shelter where the egg clutch is laid, cleaning and oxygenation of eggs, is typical of many loricariids. On the other hand, the slow development, including delayed eye degeneration, low body growth rates and high estimated longevity (15 years or more) are characteristic of precocial, or K-selected, life cycles. In the absence of comparable data for close epigean relatives (Ancistrus spp.), it is not possible to establish whether these features are an autapomorphic specialization of the troglobitic A. cryptophthalmus or a plesiomorphic trait already present in the epigean ancestor, possibly favoring the adoption of the life in the food-poor cave environment. We briefly discuss the current hypotheses on eye regression in troglobitic vertebrates.
\end{abstract}

O cascudo troglóbio (exclusivamente subterrâneo), Ancistrus cryptophthalmus (Loricariidae, Ancistrinae) é conhecido de quatro cavernas na área cárstica de São Domingos, bacia do alto rio Tocantins, Goiás. Estas populações diferem quanto ao formato geral do corpo e grau de redução dos olhos e da pigmentação cutânea. A pequena população encontrada na caverna Passa Três (aproximadamente 1.000 indivíduos) é a que apresenta os olhos mais reduzidos, não visíveis externamente nos adultos. Um grupo de um macho e três fêmeas provenientes dessa caverna reproduziu-se espontaneamente três vezes em laboratório, no fim do verão, em 2000, 2003 e 2004. Descrevemos aqui o comportamento reprodutivo observado em 2003, assim como o desenvolvimento das proles de 2003 e 2004, com foco no crescimento corporal e regressão ontogenética dos olhos. O cuidado parental pelo macho, que inclui defesa do abrigo rochoso onde os ovos eram aderidos e limpeza e oxigenação destes, segue o padrão típico de loricarí́deos. Por outro lado, o desenvolvimento relativamente lento, incluindo a regressão tardia dos olhos (iniciando aos 12 meses de idade), as baixas taxas de crescimento corporal e a alta longevidade estimada (mais de 15 anos) são característicos de ciclos de vida do tipo "precoce”, ou K-selecionados. Na ausência de dados comparáveis para os aparentados epígeos próximos, não é possível estabelecer com exatidão se tais características se tratam de adaptações autapomórficas da espécie cavernícola ou de pré-adaptações (exaptações) dos ancestrais epígeos, as quais poderiam ter favorecido a colonização do meio subterrâneo. Finalmente, apresentamos uma breve discussão sobre as hipóteses correntes acerca da regressão dos olhos em vertebrados troglóbios.

Key words: Troglobitic catfish, Brazilian caves, Regressive evolution, Reproduction, Goiás State.

Departamento de Zoologia, Instituto de Biociências da Universidade de São Paulo, C.P. 11461, 05422-970 São Paulo, Brazil. sanoverkill@yahoo.com.br (SS); etrajano@usp.br(ET) 


\section{Introduction}

Throughout the world, more than 125 species of troglobitic (exclusively subterranean) fishes are known, most from China, Brazil, Mexico and southeastern Asia (Proudlove, 2006: 281; Mattox et al., 2008). In Brazil, 24 species have been found so far, many still undescribed, which differ in their degree of troglomorphism, from species with slightly (but significantly) reduced eyes and melanic pigmentation, to those with variably developed eyes and pigmentation, and those completely eyeless and depigmented. Most are siluriforms, with two armored catfishes belonging to the genus Ancistrus, A. cryptophthalmus Reis, 1987, from cave streams in the State of Goiás (Central Brazil), and A. formoso, Sabino \& Trajano, 1997, from flooded caves in State of Mato Grosso do Sul (southwestern Brazil). A third troglobitic species of Ancistrus, A. galani Perez \& Viloria, 1994, is known from Venezuela.

The two Brazilian armored catfishes differ not only in habitat but also in their degree of troglomorphism, basically the reduction of eyes and pigmentation. The $A$. formoso population is homogeneously depigmented and eyeless, whereas the four known populations of A. cryptophthalmus exhibit a mosaic of states of regression of eyes and pigmentation, with intrapopulational variation, but none is completely depigmented and eyeless. Moreover, these populations differ among themselves and also in relation to the sympatric epigean Ancistrus sp. (undescribed species) in general body shape (Reis et al., 2006), indicating at least a partial isolation among them. Therefore, they constitute an excellent material for comparative studies focusing on the regression of eyes and pigmentation, a general feature of troglobites.

There are relatively few data on reproduction in troglobitic fishes, and even less about reproductive and egg laying behavior and parental care of the offspring. Publications with data on reproduction and life cycles in troglobitic fishes include the classical study on the North American amblyopsids by Poulson (1963) and several publications on the Mexican cave tetra characins, genus Astyanax (e.g., Wilkens, 1988; Parzefall, 1993).

The scarcity of data on reproduction in subterranean fishes is understandable. A common adaptation to the hypogean way of life is the K selected (or precocial) life cycle, characterized by a low fertility and infrequent reproduction, with a lower number of mature individuals at a given time than in epigean relatives. This, associated with low population densities, makes it difficult to observe reproductive interactions in loco and to obtain statistically significant samples. Moreover, in our extensive fieldwork in Brazilian caves, we never found eggs or very young individuals, indicating that these life stages are spent in well hidden, possibly inaccessible habitats. Therefore, almost all data on early stages of life cycles of troglobitic fishes come out from laboratory studies.

The regression of eyes is one of the most striking features of troglobites. Accordingly, it is the character related to the hypogean way of life that has been receiving the greatest attention by researchers on subterranean biology. Studies on some fishes and salamanders have shown that these animals are born with structurally normal eyes, which regress along the ontogeny (Thinès, 1960, citing Anoptichthys jordani and Caecobarbus geertsi), due to the progressive degeneration of the different structures, first the lens and cornea and at last the retina and optical nerve (Peters \& Peters, 1973; Wilkens, 1988, 2001). The evolutionary truncation of this process would result in individuals with less regressed eyes, rudimentary or just smaller than in the epigean relatives.

As in the case with reproductive studies, the investigation of eye regression is hampered by the difficulty to reproduce many of the troglobitic species in laboratory or to find the larvae in the natural habitat. The eye degeneration has been studied in deep detail in the Mexican epigean and cave Astyanax mexicanus (Characiformes), which easily reproduce and hybridize in laboratory (e.g., Peters \& Peters, 1973; Durand, 1979; Wilkens, 1987, 1988; Jeffery, 2005). Other studied subterranean fishes include Lucifuga subterraneus (Ophidiiformes) collected in the field (Durand, 1998), and Rhamdia zongolicensis and $R$. reddelli (Siluriformes) (Wilkens, 2001) and Phreatichthys andruzzii (Cypriniformes) (Berti et al., 2001; Aden, 2008), based on induced reproduction in laboratory.

The present study is part of a broader investigation on the epigean and cave armored catfishes, Ancistrus spp., from São Domingos karst area (State of Goiás, Central Brazil), which included ecology, biology, morphology and behavior, both in the field and in laboratory (Trajano, 2001; Bessa \& Trajano, 2002; Reis et al., 2006; Trajano \& Bichuette, 2007). It was made possible because a small group from Passa Três Cave reproduced spontaneously in laboratory.

There are many available data on reproduction and development of loricariids, but the majority focused on hypostomines and loricariines, with few data for ancistrines.

Therefore, this is a contribution not only to the knowledge of the ontogenetic development and eye regression in a troglobitic fish, which is the first Brazilian subterranean fish species studied under this aspect, but also to the reproduction and early life cycle in an ancistrine.

\section{Material and Methods}

Study Area. The São Domingos karst area is situated in the Cerrado domain (savannah-like vegetation), characterized by a tropical semi-humid climate, with a typical dry season in April-September. This limestone area harbors several large cave systems crossed by streams, located within the limits of the Terra Ronca State Park, São Domingos County, State of Goiás. Such streams, with epigean and hypogean reaches, run parallel westwards, contributing to form the Paranã River, one of the main tributaries of the Tocantins River, in the Amazon basin (Trajano \& Bichuette, 2007). For a detailed description of the area, with maps, see Bichuette \& Trajano (2003) and Reis et al. (2006).

The São Domingos area distinguishes worldwide by its 
rich ichthyofauna, which includes a high diversity of nontroglomorphic species, several probably troglophilic (Bichuette \& Trajano, 2003), and seven troglobitic ones: the siluriforms A. cryptophthalmus (Loricariidae), Ituglanis passensis Fernández \& Bichuette, 2002, I. bambui Bichuette \& Trajano, 2004, I. epikarsticus Bichuette \& Trajano, 2004, I. ramiroi Bichuette \& Trajano, 2004 (Trichomycteridae) and Pimelodella spelaea Trajano, Reis \& Bichuette, 2004 (Heptapteridae); and the knifefish Eigenmannia vicentespelaea Triques, 1996 (Gymnotiformes: Sternopygidae).

The ecology of the populations living in the Angélica Cave (13 $21^{\prime}$ 'S $46^{\circ} 23^{\prime} \mathrm{W}$, at the sinkhole entrance) and in the Passa Três Cave ( $13^{\circ} 25^{\prime} \mathrm{S} 46^{\circ} 22^{\prime} \mathrm{W}$, idem) was studied in detail (Trajano, 2001; Trajano \& Bichuette, 2007). During this study, some living specimens were brought alive to the laboratory for behavioral studies.

Passa Três water temperatures, measured in different occasions at sectors where catfish were regularly found, varied from 19 to $23^{\circ} \mathrm{C}$ at $100 \mathrm{~m}$ from the entrance, tending to stabilize around $21^{\circ} \mathrm{C}$ in deeper sectors, more than $300 \mathrm{~m}$ far from the entrance; higher temperatures were observed in Angélica Cave, varying annually from 22.5 to $25^{\circ} \mathrm{C}$, with recorded daily variations of $1^{\circ} \mathrm{C}$ at sectors $700 \mathrm{~m}$ far from the entrance.

Methods. Our study was mainly based on a small reproducing group of Ancistrus cryptophthalmus catfish from Passa Três Cave, with one male (67.6 mm total length $-\mathrm{TL}=$ snout to tip of the caudal fin, in May 2005) and three females (respectively 65.1, 77.2 and $81.6 \mathrm{~mm}$ TL, idem).

The fish were kept since their capture in October 1998, by hand-netting after visual inspection of the cave stream, in a 100-l tank (bottom area $=1825 \mathrm{~cm}^{2}$ ) provided with biological filter and limestone blocks for sheltering. They were fed once a week with commercial food for bottom fish (Alcon). The fish reproduced spontaneously at least thrice, in the summer of 1999-2000 (the reproductive event was noticed in May 2000, when five young, 16-17 mm TL, were observed in the tank), and again in February-March 2003 and in March 2004. The present study is based in the two latter events, although the observations relative to the eggs and clutch tending were restricted to the 2003 event, because the 2004 one was only noticed after the presence of free-swimming larvae already outside the shelter.

The catfish were kept under constant darkness (except during the maintenance activities), in a laboratory in the basement of the Departamento de Zoologia do Instituto de Biociências da USP, in São Paulo city, SE Brazil, where the temperature variations were minimized - although daily fluctuations were negligible, the air temperature varied annually between $17^{\circ} \mathrm{C}$ (June to August) and $25^{\circ} \mathrm{C}$ (December to February). In April 2005, a system of air conditioning was installed, keeping a constant temperature around $22^{\circ} \mathrm{C}$ throughout the year, which is an average temperature for the 19 troglobitic fish species maintained in our laboratory; this temperature is very close to the mean annual temperature in
Passa Três Cave $\left(21^{\circ} \mathrm{C}\right.$, see above). No reproductive event occurred in A. cryptophthalmus after the air-conditioning was installed.

The adults were observed in their home tank during the maintenance activities. When the presence of eggs was noticed due to a change in the adult behavior, we made daily observations until no egg was found. In order to count the number of eggs and follow their development, the rock forming the ceiling of the male shelter, where the eggs were adhered, was carefully turned, observed under the water and quickly returned to the original position. The diameter of the eggs, including the hyaline turgid outer membrane, was measured under stereomicroscope with a scale in one of the ocular lenses. The parental care by the male and its interactions with the females were described and recorded with photographs.

The free-swimming larvae were removed from the home tank and kept in 9-l glass aquaria with aeration and limestone blocks, but no substrate or filtration system (water was partially changed when detritus accumulated on the bottom). After total re-absorption of the yolk sac, the young were fed once a week with the same food of the adults. Two young specimens (20 and $27 \mathrm{~mm}$ total length, TL), captured in Angélica Cave in March 2004 for comparisons, were maintained under the same conditions. It is noteworthy that we never succeeded to obtain spontaneous reproduction of catfish from Angélica, in spite of many attempts with different combinations of male and female individuals, kept in conditions similar to those of the Passa Três group.

Once a week, each surviving juvenile was removed from its aquarium and observed in a Petri dish filled with water. Total length was measured using a millimeter graph paper under the dish bottom. Diameter of left and right orbits and eyes, precision $0.1 \mathrm{~mm}$, were taken under stereomicroscope, 10 times magnification, with a scale in one of the ocular lenses. The study on development was based in 11 juveniles, four from the 2003 reproductive event and seven from the 2004 event, until the complete regression of both eyes.

Graphs were generated using the Statistica 6.0 (StatSoft) software. In view of the small sample sizes, these graphs were compared visually. The comparison between different loricariid species presented in Table 1 was based on data from literature.

\section{Results}

Reproductive behavior. The male always presented territorial behavior, chasing away any female that approached the entrance of its shelter (Fig. 1a). At the times when one or more females started laying eggs, it became more tolerant to their presence within the defended area. Moreover, on the two occasions when successful reproduction occurred, the fleshy tentacles on the male snout had fully developed, growing in length and thickness. The secondary sexual dimorphism in the development of their characteristic snout tentacles is typical of Ancistrus males (Fisch-Muller, 2003).

Sixty-three (63) eggs, with an average diameter around 4.0 $\mathrm{mm}$, were counted in the 2003 clutch. It was not possible to 
Table 1. Numbers of eggs per female, their diameter (mean values or observed range, in $\mathrm{mm}$ ) and reported sizes (TL, in $\mathrm{mm}$ ) of reproducing females recorded in the literature for epigean loricariids, compared to the presently observed values for the troglobitic Ancistrus cryptophthalmus from Passa Três Cave. Nomenclature and taxonomy follow Reis et al. (2003).

\begin{tabular}{lcccl}
\hline \multicolumn{1}{c}{ Subfamily/Species } & N $^{\circ}$. eggs & Egg sizes & Females sizes & \multicolumn{1}{c}{ References } \\
\hline HYPOSTOMINAE & & & & \\
Rhinelepis aspera & ----- & 1.48 & $425-605$ & Sato et al., 1998 \\
Hypostomus argus & $\sim 290$ & 3.25 & 60 & Winemiller, 1989 \\
H. leutkeni & $446-936$ & 5.2 & $70-310$ & Mazzoni \& Caramaschi, 1997 \\
H. affinis & 1.784 & $4.07-5.43$ & $80-331$ & Mazzoni \& Caramaschi, 1995 \\
H. watwata & $42-3902$ & $4.5-5.8$ & ----- & Garcia-Pinto et al., 1984 \\
H. plecostomus & ---- & 3.3 & 242 & Azevedo, 1938 \\
H. commersoni & ---- & max. 4.2 & ---- & Agostinho et al., 1982 \\
Liposarcus anisitsi & $625-834$ & $3.0-4.0$ & $375-440$ & Cruz \& Langeani, 2000 \\
L. multiradiatus & 763 & 3.5 & 233 & Winemiller, 1989 \\
LORICARIINAE & & & & \\
Loricaria simillima & $167-340$ & $2.25-2.90$ & $215-280$ & Taylor, 1983 \\
Pseudohemiodon laticeps & $60-291$ & 5.24 & $104-208$ & Lopez \& Machado, 1975 \\
Rineloricaria uracantha & ----- & 3.0 & $83-108$ & Moodie \& Power, 1982 \\
Loricariichtys labialis & 508 & $1.95-2.50$ & 195 & Taylor, 1983 \\
L. platymetopon & $464-850$ & $2.52-4.14$ & $220-290$ & Marcucci et al., 2005 \\
L. typus & 92 & 3.44 & $91.5-189$ & Machado \& Lopez, 1975 \\
ANCISTRINAE & & & & \\
Chaetostoma thomsoni & $70-80$ & 4.0 & 90 & Seidel, 1998; Torrens, 2006 \\
Peckoltia vittata & ---- & $2.5-3.0$ & $80-85$ & Ekström, 2006 \\
Hypancistrus zebra & $7-12$ & $4.0-5.0$ & 94 & Seidel, 1996 \\
Ancistrus claro & $20-30$ & ---- & 80 & Seidel, 1998 \\
A. cf. triradiatus & $50-90$ & 2.0 & ---- & Geerinckx et al., 2008 \\
A. cryptophthalmus & 63 & 4.0 & $65-81.6$ & Present data \\
\hline
\end{tabular}

establish how many and which individual females contributed to this egg clutch. The eggs, initially with a golden-yellow coloration, were adhered to the smooth, flat rock forming the ceiling of the shelter (Fig. 1b). A free space was left between the eggs and the shelter entrance, where the male positioned itself. After beginning of the spawning, the male started displaying parental care (in the ethological sense; Crawford \& Balon, 1996), restoring an enhanced territorial behavior, which encompassed an area with radius of $c a .9 \mathrm{~cm}$ from the shelter entrance (Fig. 1c). Approaching females were chased away using lateral head strokes, with the odontodes (extraoral, teeth-like structures situated on the operculum border, typical of the Loricarioidei; Pinna, 1998) exposed through elevation of the operculum, or attacks towards the female dorsum followed by biting attempts. These aggressive behaviors were frequently observed during the first two weeks, with the male remaining inside the defended perimeter even when foraging, until the first free living larvae (Fig. 1d, top right) were found outside the shelter.

When not foraging or chasing females away, the male remained upside down on the shelter ceiling, beating softly the pectoral and ventral fins which created a water flow over the eggs, probably to help their oxygenation. In addition, it regularly cleaned the eggs with the mouth, passing the fresh lips over them. Probably, unviable eggs and dead larvae were ingested, because none of them was ever observed.

After the appearance of the first free swimming larvae, the male started leaving the defended territory for short periods, but the parental care proceeded until all embryos were gone. All the process, from the appearance of the first eggs to the extinction of the parental care, totaled two weeks.

For intra-family comparisons, the number and diameter of eggs, as well as sizes (TL) of reproducing females, in $A$. cryptophthalmus and in other studied loricariids (data from literature), are shown in Table 1.

Development of juveniles and eye regression. The larvae started hatching five to six days after the eggs were first noticed. The newly hatched larvae had around $10.5 \mathrm{~mm}$ TL, exhibiting black symmetrical eyes measuring around $0.4 \mathrm{~mm}$ in diameter, without distinct pupils (Fig. 1d). They aggregated on corners deep inside the shelter, intensively vibrating the tail and occasionally swimming for short distances. These larvae started leaving the shelter, some of them since the first days, swimming swiftly for short distances with the head close to the substrate (bottom or tank walls), body upheld on the yolk sac and tail turned up, and frequently resting for long periods on rock corners or midway on the tank walls. This positively thigmotropic behavior was also observed after the larvae were transferred to the glass aquaria. Here they preferred corners formed by joining walls, staying in a vertical position with the head towards the bottom and concentrating over the bubbling water current created by the aeration flow, thus exhibiting a rheotactic behavior. The yolk sac was completely absorbed six to seven days after hatching. From this time on, the juveniles exhibited strong cryptobiotic habits, hiding in spaces between rocks.

The individual growth rates of the 2003 and 2004 offsprings are respectively shown in Figs. 2 and 3. Mean values (and ranges) of growth rates for the first semesters of life of these specimens are shown in Table 2.

Individual differences in growth rates were observed for the laboratory born Passa Três catfish, especially in the 2004 offspring (Fig. 3): when 18 months old, the smaller fish had 

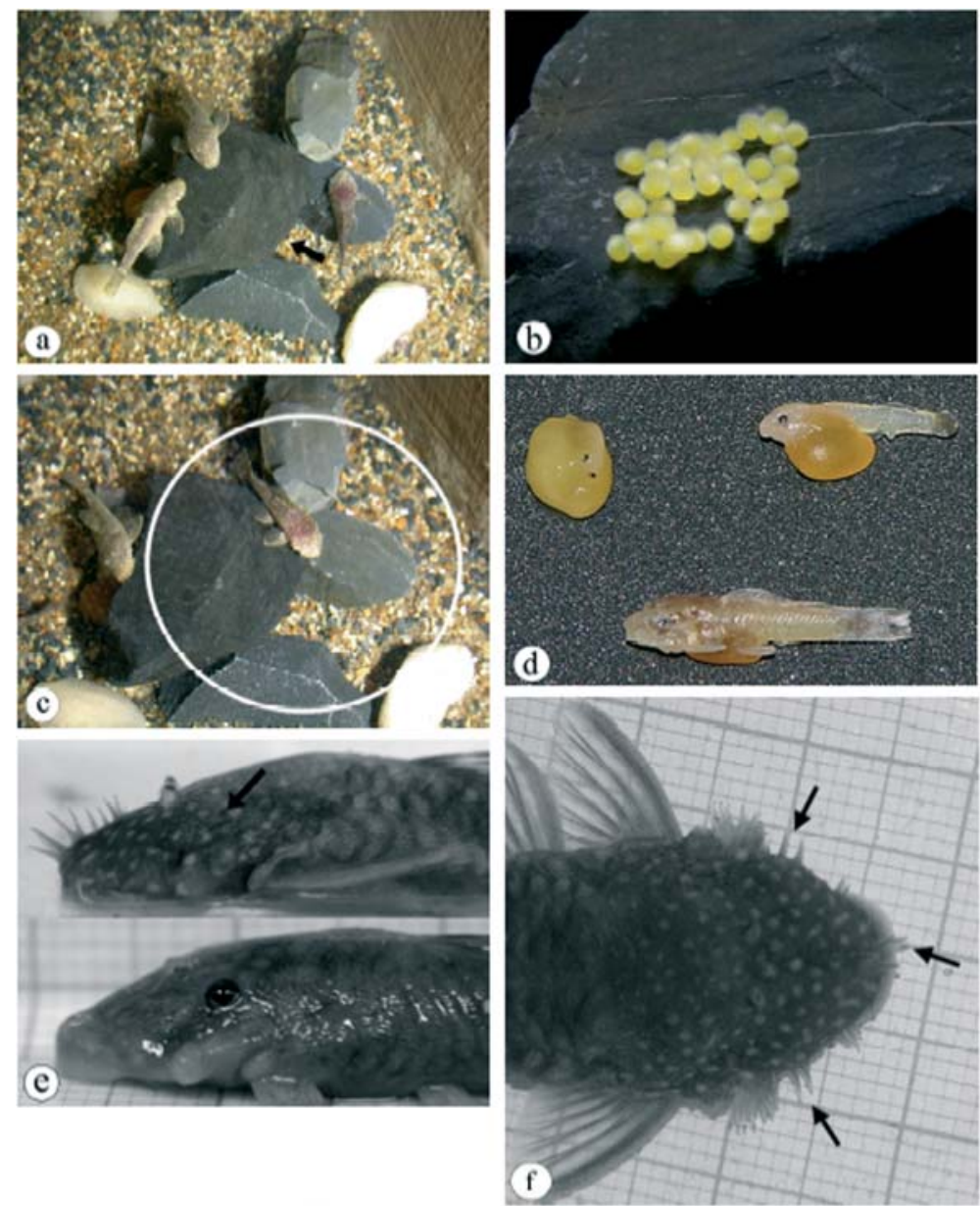

Fig. 1. (a) Reproductive adults of Ancistrus cryptophthalmus from Passa Três Cave kept in laboratory: two females (to the left) and male (to the right, dorso-posterior region of the head red-colored); arrow indicates the entrance of the shelter occupied by the male. Photograph taken on April 2004. (b) Cluster of eggs adhered to the ceiling of the shelter, average diameter $=4.0 \mathrm{~mm}$. (c) Area around the shelter entrance (within the white circle) defended by the male (close to the center of the circle). (d) Clockwise from the top left: embrio (eyes visible), newly hatched larva (10.4 mm TL), more advanced larva (12.5 mm TL), with yolk-sac almost completely absorbed. (e) Top: $53 \mathrm{~mm}$ long juvenile from Passa Três Cave, with regressed eyes; arrow indicates the orbit reduced to a small depression covered with skin. Bottom: $53 \mathrm{~mm}$ long juvenile from Angélica Cave, probable the same age as the former, showing non-regressed eyes. (f) Detail of the head of the juvenile from Passa Três; arrows indicate the first primordia of tentacles.

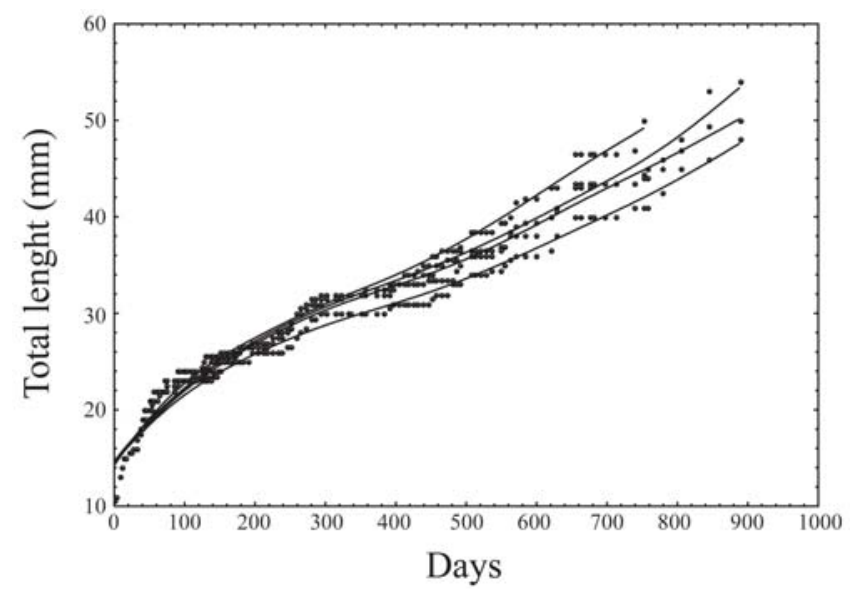

Fig. 2. Size (total length, in mm) versus age (in days) in four specimens of Ancistrus cryptophthalmus from Passa Três Cave born in laboratory in March 2003.

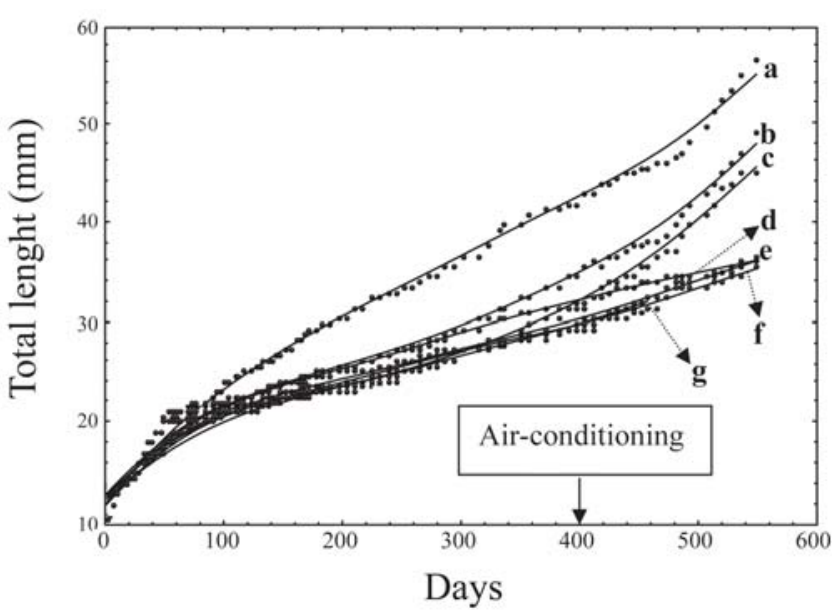

Fig. 3. Size (total length, in mm) versus age (in days) in seven specimens (respectively a to g) of Ancistrus cryptophthalmus from Passa Três Cave born in laboratory in March 2004. 
Table 2. Mean values (and ranges) of growth rates (in $\mathrm{mm}$ ) for the first semesters of life of Ancistrus cryptophthalmus individuals born in laboratory. The rates relative to the individuals born in 2004 (2004 offspring) are shown separately: for all semesters, the single fast growing (f.g.) specimen was separated from the other six; for the third and fourth semesters of life, the remaining group (one fish died) was separated in two.

\begin{tabular}{lccccc}
\hline \multicolumn{1}{c}{ Offspring } & $1^{\text {st }}$ sem. & $2^{\text {nd }}$ sem. & $3^{\text {rd }}$ sem. & $4^{\text {th }}$ sem. & $5^{\text {th }}$ sem. \\
\hline $2003(\mathrm{~N}=4)$ & $2.6(0.5-6.5)$ & $1.0(0.5-3.0)$ & $3.2(0.5-2.5)$ & $1.2(0.5-3.5)$ & $3.0(0.5-3.5)$ \\
2004 f.g. $(\mathrm{N}=1)$ & 3.3 & 1.9 & 2.2 & 4.0 & \\
$2004(\mathrm{~N}=6)$ & $2.4(2.2-2.6)$ & $0.84(0.66-1.2)$ & & & \\
& & $2004(\mathrm{~N}=2)$ & $0.95(0.83-1.1)$ & 2.0 & \\
& & $2004(\mathrm{~N}=3)$ & $1.9(1.0-2.4)$ & $3.5(2.5-4.2)$ & \\
\hline
\end{tabular}

attained $35 \mathrm{~mm}$ TL and the larger, $55 \mathrm{~mm}$ TL (in average, 3 $\mathrm{mm}$ month $\left.^{-1}\right)$. During the first and second semester of life, the growth rates of the 2003 catfish (Fig. 2) were similar to those of the 2004 specimens (except for the fast-growing one); in the second year of life, the growth rates were rather erratic for both offsprings (Table 2). The growth rates recorded for the two juveniles caught in the Angélica Cave were within the range observed for the fish from Passa Três Cave (Fig. 4).

By the end of the first semester of life (ca. 160 days, catfish size $\sim 26 \mathrm{~mm} \mathrm{TL}$ ), it was observed an increment in the eye diameter, from 0.4 to $0.5 \mathrm{~mm}$, in average. After a long time of structural stasis (ca. 270 days), the eye regression started being externally visible and two consecutive phases could be distinguished. In the first phase, the only modification detected along several months was the reduction of dark pigmentation of the eyes. A second, subsequent phase was characterized by the disorganization of the eye structure. This phase began in individuals $\sim 45 \mathrm{~mm}$ TL with the degeneration of the eye circular shape, gradually changing into a horseshoe shape with the concave border directed towards the external margin of the orbit. The second phase was clearly recognizable in juveniles ca. 380 days old. It was followed by a gradual sinking of the eyes into the ocular cavity and a further change in their shape: the two ends of the horse-shoe shaped sinking eyes approached and eventually touched and merged, resulting in elliptical eyes, smaller than in the previous phase and with a central slit. Concomitantly with the eye sinking,

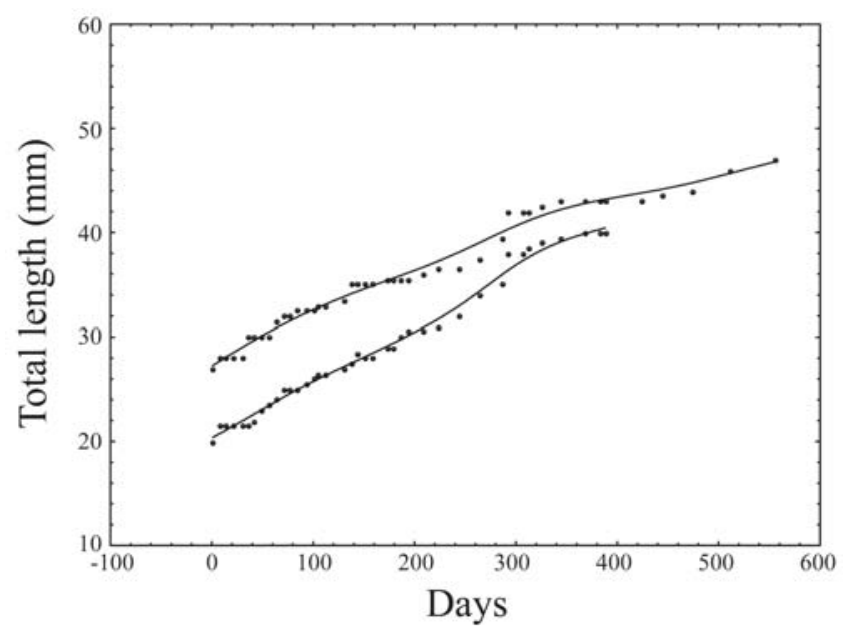

Fig. 4. Size (total length, in mm) versus age (in days) of two wild caught specimens of Ancistrus cryptophthalmus from Angélica Cave kept in laboratory. two or three skin folds began to protrude from the walls of the ocular cavity, growing centripetally and eventually covering the regressing eyes. Apparently a centripetal growth of bones in the circumorbital region contributed to close (but not completely) the orbits. These orbits ended as small depressions covered by skin in the fish from the Passa Três population, as observed in two years old individuals (Fig. 1e, top).

The left eye sizes in relation to the increment of size (total length) in each of the seven specimens of the 2004 offspring of Passa Três catfish are shown in Fig. 5. The observed regression was never simultaneous for the two eyes (Fig. 6), resulting in a highly asymmetrical condition. In some

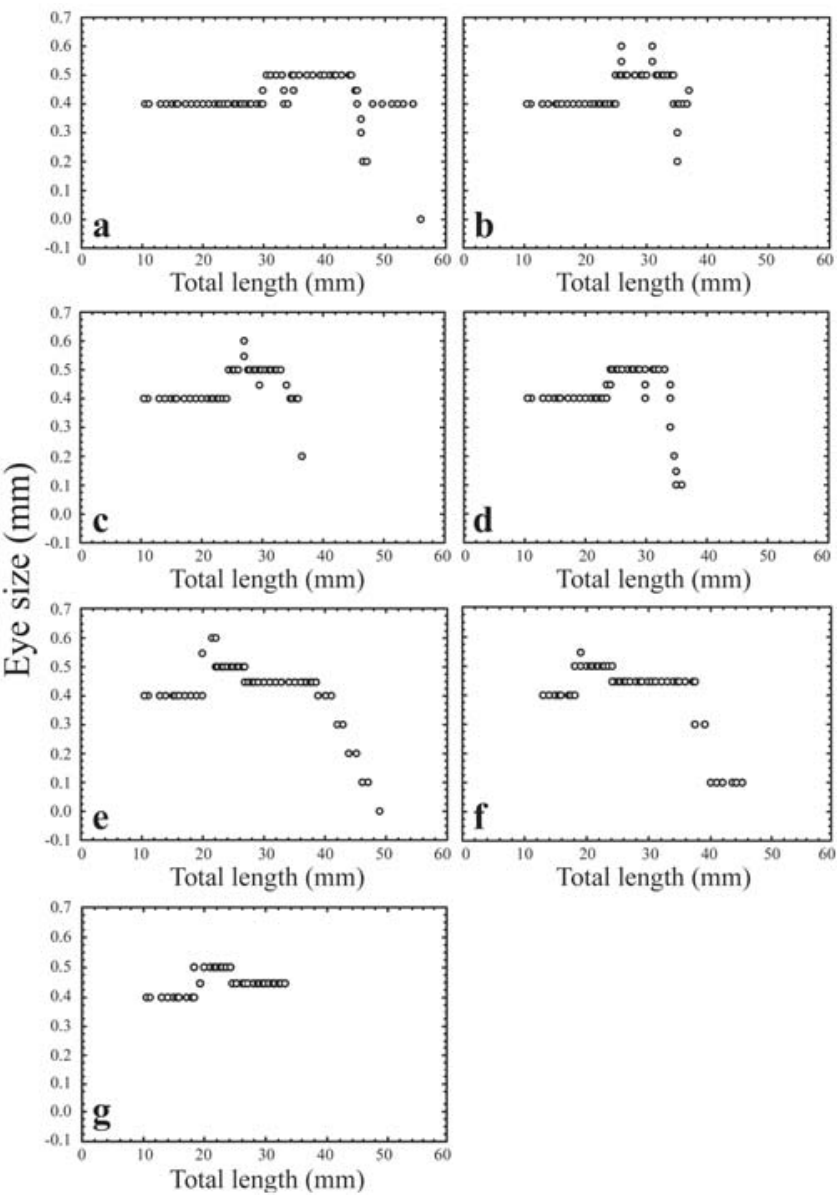

Fig. 5. Left eye size (diameter, in mm) versus total length (in $\mathrm{mm}$ ) in the seven specimens (respectively a to g) of Ancistrus cryptophthalmus of the Passa Três 2004 offspring. 
individuals the left eye started degenerating first, in others the right eye degenerated before, hence during the phase of regression a mosaic distribution was observed for the eye condition in the studied sample. The sinking of both eyes into the orbits was completed in 924 to 950 days in the 2003 offspring ( $\mathrm{N}=4)$ and 480 to 584 days in the 2004 offspring ( $\mathrm{N}$ $=7$ ). For the only juvenile captured in the Angélica Cave and surviving long enough in laboratory, both eyes attained simultaneously the maximum size (1.9 mm in diameter) when the fish was $50.5 \mathrm{~mm}$ long, beginning to regress at this point. Nevertheless, the regression was not complete (Fig. 1e, bottom), as also observed in the cave habitat where the great majority of adults and all youngsters present externally visible, variably sized eyes.

When the juveniles from Passa Três Cave reared in laboratory reached sizes around 5.0-6.0 mm TL, snout tentacles, typical of Ancistrus catfishes and more developed in males, began to form. Tentacle primordia first appeared on the snout tip and on the lateral-posterior rostral borders (Fig. 1f). Subsequently, new tentacles started growing between these points, filling the spaces between the first tentacles, and also on the dorso-medial region of the head. These tentacles are fully developed in reproductive males, females and juvenile males present only very short tentacles.

A graphical summary of the life cycle of $A$. cryptophthalmus from Passa Três Cave is shown in Fig. 7.

\section{Discussion}

Reproduction, growth and lifespan. Loricariids, in special hypostomines and loricariines, characteristically produce a relatively small number of large eggs, which are frequently laid in protected places, and present parental care of the offspring ("guarding" behavior), usually by the male (Breder \& Rosen, 1966; Blumer, 1982; Moodie \& Power, 1982; Mazzoni \& Caramaschi, 1997).

Most loricariids deposit egg clutches adhered to the substrate (plants, holes in logs, rock crevices etc.), presenting parental care usually displayed by the male, including territorialism and tending of eggs and newly hatched larvae (Breder \& Rosen, 1966; Blumer, 1982; Balon, 1981). Within the classification of reproductive styles in fishes summarized by Crawford \& Balon (1996), these fishes enter the ethological section of "guarders". Parental care by the male was recorded for the majority of studied species, such as the loricariines Loricaria simillima, Loricariichthys latymetopon and $L$. labialis (Taylor, 1983), and the hypostomines Liposarcus anisitsi (actually Pterygoplichthys ambrosettii) (Cruz \& Langeani, 2000) and Hypostomus watwata (Garcia-Pinto et al., 1984). The loricariine Ricola macrops, in which the parental care is displayed by females (Hordes, 1945) seems to be an exception within the loricariids. Therefore, even in the absence of robust data for ancistrines, the reproductive behavior herein described for the cave armored catfish, Ancistrus cryptophthalmus, including territorialism and parental care through guarding of eggs and young larvae by the male, is in accordance with the observed for epigean loricariids in general.

Ancistrus cryptophthalmus catfish are, as expected for a cave species, rock tenders. Observations on epigean Ancistrus catfish in the same and other areas (pers. obs.) indicated a strong preference to rocky substrates, and this may be typical for the genus. Thus, this is probably a plesiomorphic condition for A. cryptophthalmus, which had favored the adoption of the subterranean life by its ancestor.
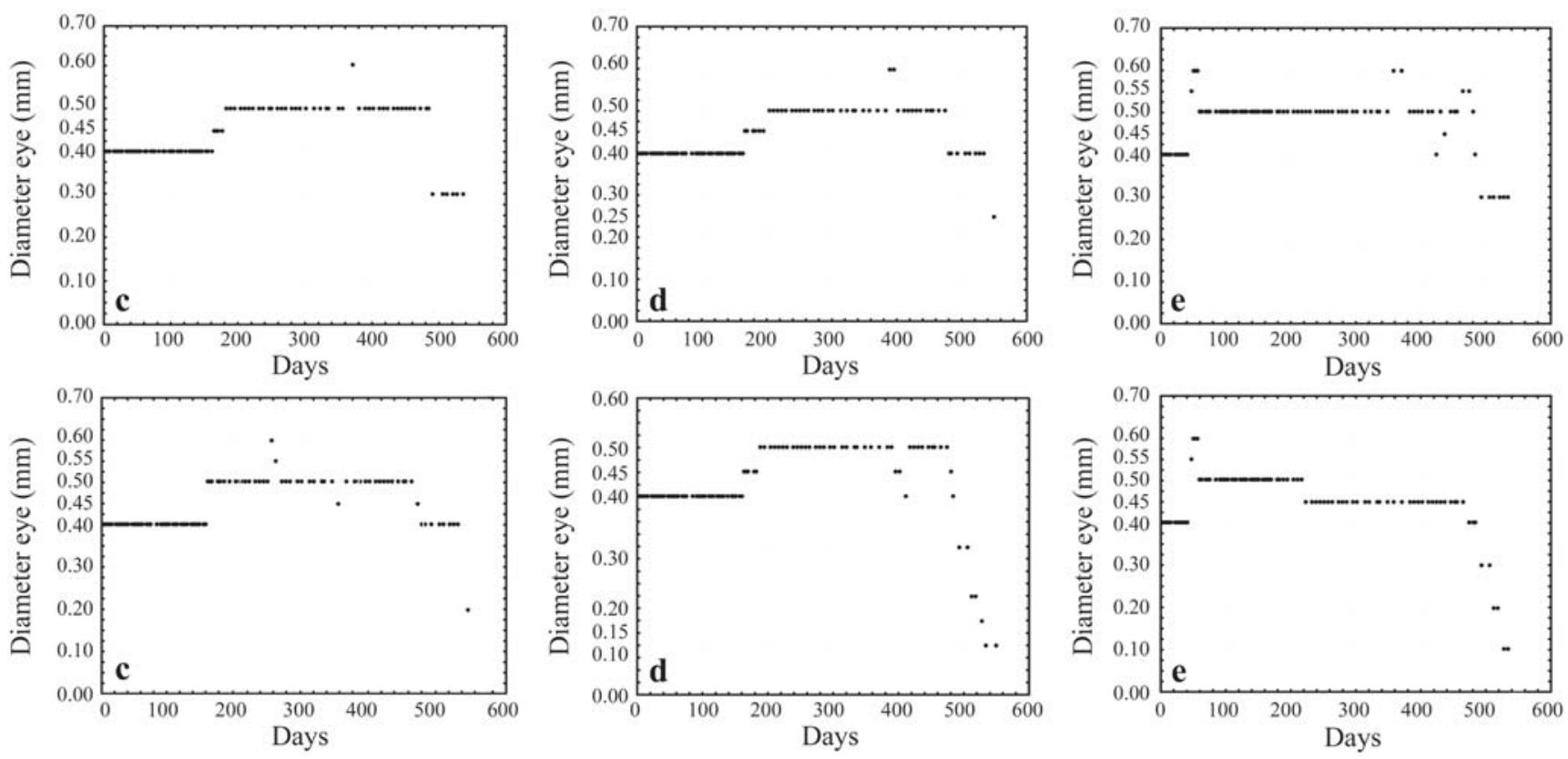

Fig. 6. Eye size (diameter, in mm) versus age (in days) in three selected specimens (from left to right) of Ancistrus cryptophthalmus from Passa Três Cave; right eye on the top, left eye on the bottom. 


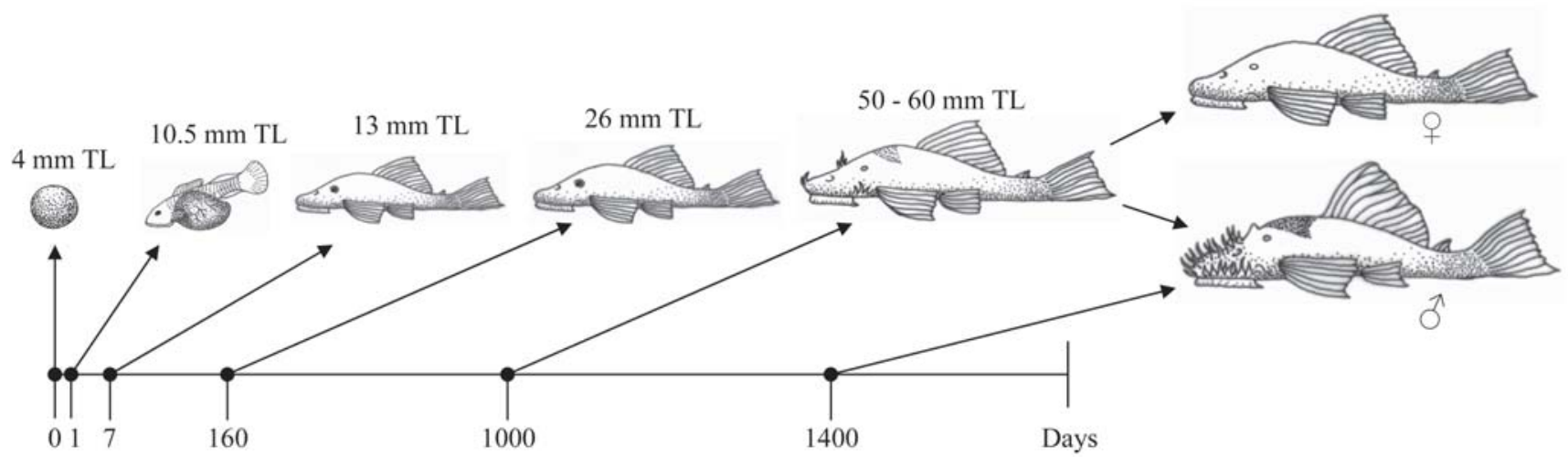

Fig. 7. Summary of the life cycle of Ancistrus cryptophthalmus from Passa Três Cave.

Cleaning of the eggs observed for Ancistrus cryptophthalmus in laboratory, probable to remove dead eggs and larvae, and attached particles washed in by the water current by the male for oxygenation of the egg clutch, was also reported for Rineloricaria uracantha (actually Fonchiiichthys uracanthus) in a stream in Panamá (Moodie \& Power, 1982).

As mentioned, 63 eggs, each with a diameter of ca. 4.0 $\mathrm{mm}$, were counted in the clutch produced in 2003 by $A$. cryptophthalmus catfish. The number of larvae found outside the shelter in 2004 is also consistent with a relatively small number of eggs produced in this reproductive event. In view of the paucity of comparable data for other Ancistrus species, and also for ancistrines in general, more distantly related loricariids were used for comparison. This is not an ideal situation in view of the intra-family variation which, although not particularly high, hampers the visualization of well defined patterns and the establishment of transformation series allowing for consistent evolutionary interpretations

The comparison with species in which reproductive females presented sizes similar to the observed for $A$. cryptophthalmus (smallest females with developed gonads seen by transparency $~ 40 \mathrm{~mm}$ in standard length, SL; maximum SL $80 \mathrm{~mm}$; Trajano \& Bichuette, 2007) would indicate that the number of eggs produced in the former may be considered small (Table 1). Nevertheless, the number recorded for $A$. cryptophthalmus is within the range for the few ancistrines so far studied (Table 1). Hence, a relatively low number of eggs may be either a characteristic of the subfamily or of the genus, possibly related to the use of safer shelters (rock crevices), or a further specialization to the subterranean life in A. cryptophthalmus.

A lowered number of eggs, typical to the life style of many troglobitic species (Poulson \& Lavoie, 2000), is usually accompanied by an increase in the diameter of eggs (Poulson \& White, 1969; Wilkens, 1988). However, the average egg diameter measured for A. cryptophthalmus is within the range recorded for several loricariids, and approaches the observed for other ancistrines (Table 1). In the absence of data for the putative epigean sister-species or other species of the same genus, the presence of these two features as indicative of a precocial (sensu Balon, 1990), or K-selected (Culver, 1982), life style is still an open question for A. cryptophthalmus.

The same is true for the size of newly hatched larvae: these larvae are larger in A. cryptophthalmus (10.5 mm TL, 9.1 mm SL) than in Hypostomus plecostomus (4.2 mm SL; Azevedo, 1938), Loricariichthys typus (8.4 mm SL; Machado \& Lopez, 1975) and Pterygoplichthys ambrosettii (7.5 - 9.0 mm SL; Cruz \& Langeani, 2000), all reaching larger sizes than $A$. cryptophthalmus (max. SL $~ 80 \mathrm{~mm} \mathrm{SL}$ ), but smaller than in the Pseudohemiodon laticeps $(16.0 \mathrm{~mm} \mathrm{SL})$ and Fonchiiichthys uracanthus (12.0 mm SL), although the larger size reached by the latter two may explain the observed differences. In the absence of data for other ancistrines, this is also an open question.

The swimming behavior of A. cryptophthalmus newly hatched larvae was similar to the described for Hypostomus plecostomus (Azevedo, 1938), and may correspond to a pattern for armored catfishes.

No pattern is clear for the absorption time of the yolk sac in loricariids. In the hypostomine Pterygoplichthys ambrosettii, the egg sac is completely absorbed in four to six days, resulting in exogenously feeding juveniles 11.0 to 13.0 $\mathrm{mm}$ SL (Cruz \& Langeani, 2000). The absorption time is longer in Ancistrus cryptophthalmus, six to seven days, resulting in juveniles with 12.2 to13.6 mm SL. However, in A. cf. triradiatus it takes 22 days for complete absorption of the yolk sac, resulting in juveniles with $11.2 \mathrm{~mm}$ SL (Geerinckx et al., 2008). Twenty seven (27) days after hatching, juveniles of another hypostomine, Kronichthys subteres, reach $20.0 \mathrm{~mm}$ TL (Buck, 1994), whereas A. cryptophthalmus juveniles are $16.0 \mathrm{~mm}$ TL after the same time.

The relatively large size of hatching larvae in $A$. cryptophthalmus from Passa Três was followed by low growth rates from the beginning of the exclusively exogenous feeding stage. The average growth rates during the first years in laboratory were estimated in $2.3 \mathrm{~mm} \mathrm{month}^{-1}$ in the first semester of life, decreasing and then staying around 0.7-0.8 $\mathrm{mm}$ month $^{-1}$ in the subsequent four semesters. Low rates were also recorded in the natural habitat for individuals larger than $30 \mathrm{~mm}$ SL (probably one year old), during a study carried out in the dry seasons of 1999 and 2000 in both Passa Três and 
Angélica caves (Trajano \& Bichuette, 2007): consistently around $0.5 \mathrm{~mm} \mathrm{month}^{-1}$ in the former, but varying according to the size in the latter, with $0.7 \mathrm{~mm} \mathrm{month}^{-1}$ for individuals smaller than $42 \mathrm{~mm} \mathrm{SL}$ and $0.35 \mathrm{~mm} \mathrm{month}^{-1}$ for the larger ones. Moreover, some catfish lived for almost 10 years in laboratory, as is the case with the reproducing group from Passa Três. Since these individuals were already adults, with 50-60 mm TL when brought to laboratory, their lifespan would be around 20-25 years, with a particularly slow growth in the late life stages, at least in laboratory (our reproducing male has $68 \mathrm{~mm}$ TL, June 2007).

This is the first study on Brazilian troglobitic fishes to fill an important gap in the knowledge of the growth rates in juvenile troglobitic fishes. The population ecology of other Brazilian cave fish has been investigated (Trajano, 1991, 1997b; Trajano \& Bichuette, 2007), but the use of marking and recapture techniques restricted such studies to individuals large enough to be marked. Therefore, estimates of longevities lose accuracy due to the unknown age of specimens smaller than the minimum size for marking.

In the cave habitat, the growth rates recorded $A$. cryptophthalmus were close to those estimated for the heptapterid Pimelodella kronei (Trajano, 1991); the absolute values in $P$. kronei are twice those in A. cryptophthalmus, but the former reaches double the size for the latter. These species live in ecologically similar habitats. The growth rates of armored catfish in laboratory are somewhat lower than in the similarly sized troglobitic trichomycterid catfish, Trichomycterus itacarambiensis, fed ad libitum (Trajano, 1997b). On the other hand, the average growth rates of both T. itacarambiensis and Pimelodella spelaea (Trajano et al., 2004), estimated in the natural habitat during dry seasons, tended to zero, indicating a regime of severe food limitation in this season and growth in pulses along the annual cycles. Although food may be relatively scarce, apparently A. cryptophthalmus populations are not subject to such cycles including phases of severe limitation of energy.

Important individual differences in growth rates of $A$. cryptophthalmus were observed for the laboratory born specimens, kept under the same general conditions of space and available food. Hence, these armored catfish may represent a further instance of heterogeneous growth, as reported for several epigean teleost fishes (Volpato \& Fernandes, 1994). These differences would be due to a growth reduction in most individuals, referred as growth suppression. The causes of this phenomenon, either genetic or environmental (especially social), are not fully understood.

The divergence in individual growth rates continued after the air conditioning was installed in the laboratory and temperature stabilized around $22^{\circ} \mathrm{C}$ (see Tables 2 and 3). In the cave habitat, the armored catfish were found to be sedentary and the distribution of size classes did not differ among sectors with variable and non-variable temperatures. Therefore, temperature variations seem not to significantly affect the growth and eye regression rates in this species.

Trajano \& Bichuette (2007), based on growth rates obtained for A. cryptophthalmus through mark-recapture in the cave habitat, conservatively proposed a longevity of 810 years for fish $70 \mathrm{~mm} \mathrm{SL}$ (theoretical maximum size calculated using the von Bertalanffy model). The present data on growth rates in juveniles allow a reasonable extension of the estimated average longevity to 15 or more years.

Potential predators for armored catfish were identified in the Passa Três Cave, represented by erythrinids living in deep pools that intercalate with the riffles where $A$. cryptophthalmus concentrate. Small to medium sized catfish entering these pools may be swallowed by the erythrinids, as we observed by releasing a few specimens in such pools. In addition, sizerelated dominance based on aggressive behaviors was observed in laboratory for defense of food but not shelter (Trajano \& Souza, 1994). Catfish overcoming a critical body size would escape from predation and dominate over the great majority of conspecifics, greatly enhancing their chances to find food and mates without being predated. Such individuals could go on growing and become size outliers up to $80 \mathrm{~mm} \mathrm{SL}$ (Fig. 2, Trajano \& Bichuette, 2007), reaching longevities of 20 or more years.

A short larval stage, with fast development into an adult miniature (direct ontogeny), capable of cope with relatively strong water currents, is a clear adaptation to life in streams (Reihl \& Patzner, 1991). In the São Domingos karst area, the habitat characteristics and pluviometrical regime is similar for epigean and hypogean reaches of base-level streams, as those inhabited respectively by the epigean Ancistrus sp. and A. cryptophthalmus. Therefore, morphological and locomotor adaptations to fast-flowing waters have been retained in the cave populations. Likewise, the photophobic and cryptobiotic habits of A. cryptophthalmus larvae are consistent with the general tendency within siluriform fishes.

On the other hand, the hatching of relatively large larvae, slow growth and high longevities are consistent with a precocial life style, as observed in many troglobites and interpreted as an adaptation to survive under the food-limiting conditions characteristic of most subterranean habits.

The growth rates in laboratory recorded for two wild caught juveniles from Angélica Cave were intermediate between those exhibited by the fast growing and by the slow growing individuals from Passa Três. No important differences in growth rates between these two populations were detected in the natural habitat (Trajano \& Bichuette, 2007). In laboratory, individual growth rates started to significantly diverge in 300 days old individuals ( $c a .30 \mathrm{~mm}$ SL - Table 2; in the 2004 offspring, just one individual diverged early, starting when it was approximately 100 days old). Thus, it is reasonable to suppose that, for small fish (up to $30 \mathrm{~mm}$ SL), similarly sized individuals have, in average, the same approximate age. At the age in which Passa Três individuals had eyes $0.5 \mathrm{~mm}$ in diameter ( $\mathrm{SL}<40 \mathrm{~mm}$ ), those from Angélica had much larger eyes, $1.5 \mathrm{~mm}$ in diameter. These eyes continued to grow after the age in which the eyes of Passa Três catfish started degenerating. A certain variation in the eye size is observed in the Angélica population, thus sometime after an age of 18 
months, the eyes of part of the Angélica individuals would start reducing in size.

Regression of eyes. The ontogenetic regression of eyes is a common phenomenon in troglobitic vertebrates, observed in taxa as diverse as Proteidae and Plethodontidae salamanders (Durand, 1973; Durand et al., 1993), and ophidiiform, characiform, cypriniform and also siluriform fishes (Ituglanis passensis, cited as Trichomycterus sp. in Trajano \& Souza, 1994; A. cryptophthalmus from Passa Três cave, Reis, 1987). The intrinsic nature of this ontogenetic regression, suggesting a genetic basis, has been demonstrated for troglobitic Astyanax (Peters \& Peters, 1973; Durand, 1979; Wilkens, 1987, 1988; Jeffery \& Martasian, 1998) and Proteus anguinus (Durand, 1973). Apparently, the melanic pigmentation is subject to a similar process of ontogenetic regression (e.g., Vandel et al., 1969, for P. anguinus; Trajano \& Souza, 1994, for Ituglanis passensis), which is also genetically based as shown for different populations of cave Astyanax (Protas et al., 2006).

The present study is basically a study on natural history, thus our choice was to keep the fish alive in order to follow their individual development. If, on one hand, this hampered histological studies with focus on the ontogeny of eye regression because the number of surviving juveniles was relatively small, on the other hand it allowed the obtain of data scarcely available not only for cavefish but also for neotropical fishes in general. For instance, heterogeneous growth, which is a major concern for aquaculture (e.g. Volpato \& Fernandes, 1994), had been mainly focused on studies regarding few neotropical species distantly related to Ancistrus catfishes.

In the absence of histological data, direct comparisons with other studies on eye regression in troglobitic vertebrates may be questionable, and indirect evidence must be used. Although similarly large, externally visible eyes may present different levels of structural organization (as in Rhamdia reddelli; Wilkens, 2001: fig. 3), there is no reported case of large, normally organized eyes sunk into the orbits and not visible externally. Therefore, it is reasonable to suppose that sinking is an evidence of structural disorganization and that these two processes are not far apart in the ontogeny of troglobitic fishes. Thus, the late decrease of eye sizes and sinking into the orbits is evidence for a late eye regression in the ontogenetic development of Ancistrus cryptophthalmus from Passa Três Cave.

In troglobitic Mexican tetra characins, genus Astyanax, three months old juveniles presented completely regressed eyes. An even shorter time for eye degeneration, less than 30 days, was observed for the phreatobic cyprinid Phreatichthys andruzzii (Berti et al., 2001). In contrast, the external signals of eye regression in A. cryptophthalmus started much after the short larval stage, in nine months old juveniles showing the same general morphology and habits of adults. The process of degeneration was also very long, only being complete in 18 months old individuals from Passa Três Cave.

The loss of dark pigmentation followed by the structural degeneration of eyes was also reported for the troglobitic ophidiiform Lucifuga subterranea (Durand, 1998). No trace of pigment was observed in the eyes of Phreatichthys andruzzi (Berti et al., 2001); histological studies showed that the eye degeneration in this species was accompanied by modifications in the capillary system, indicating that such regression is associated with the lack of vascularization. Similar studies are still missing for A. cryptophthalmus.

Different situations regarding the ontogeny of eyes have been reported for cave fishes: 1 ) ontogenetic eye development can be detected, but it does not result in a complete lens and in differentiated retinal layers, as observed for the highly specialized troglobitic cyprinid, Phreatichthys andruzzii, from Somalia (Aden, 2008); 2) the larval eye presents differentiated lens and retina (and respective associated structures), which regress early during the ontogeny, as is the case with the intensively studied troglobitic Astyanax, from Mexico (e.g., Langecker et al., 1993; Jeffery, 2005); 3) lens reduction and retinal regression start latter, after the larval stage, as in troglobitic Rhamdia zongolicensis and $R$. reddelli, from Mexico, which exhibit a high degree of individual variation in eye development in the adults (Wilkens, 2001), and also the presently studied A. cryptophthalmus. Variable eyes have also been observed for $R$. enfurnada, from Brazil (Bichuette \& Trajano, 2005), in which cases of externally visible asymmetrical eyes in adults are relatively frequent (Trajano et al., pers. observ.), like in $R$. zongolicensis and $R$. reddelli. The asymmetry in eye reduction is also noticeable in A. cryptophthalmus, providing evidence supporting the neutral mutation theory for eye regression (Culver \& Wilkens, 2001: "This is in accord with the high variability of the biologically functionless vestigial structures in caves species in general (Culver, 1982)").

Based on developmental studies on Mexican Astyanax cavefish, Jeffery (2005) proposed that the eyes could have been lost by default as a consequence of natural selection for constructive regression, such as feeding structures, more developed in these troglobites than in their epigean close relatives. These structures are positively regulated by Hedgehog midline signaling, whose expansion, not selected against in permanently dark habitats, would inhibit eye formation. This hypothesis, however, do not apply to the troglobitic fish in which the eye regression occurs late in the ontogeny, after the larval stage. So far, the neutral mutation hypothesis is still the most general for regressive characters, such as the eyes and pigmentation in troglobitic vertebrates.

\section{Acknowledgements}

Thanks are due to the cavers and biologists who helped us in the field and laboratory work, especially to Maria Elina Bichuette, who also helped us with the graphs. We are greatly indebted to the Fundação de Amparo à Pesquisa do Estado de São Paulo - FAPESP, for the research grant (\# 03/00794-5) and fellowship (\# 05/50191-0) granted to the first author (SS). The second author (ET) is partially supported by the Conselho Nacional de Desenvolvimento Científico e Tecnológico - CNPq (fellowship \# 302174/2004-4). Permission for collections was given by IBAMA. 


\section{Literature Cited}

Aden, E. 2008. Ontogenetic and phylogenetic aspects of regression processes in cave fish: immunohistological studies on the blind fish Phreatichthys andruzzii Vinciguerra, 1924. Pp. 8. In: $19^{\text {th }}$ International Symposium of Subterranean Biology. Fremantle, Australia, Symposium Abstracts, 109p.

Agostinho, A. A., M. Y. Narahara \& H. M. Godinho. 1982. Morfologia dos ovários de Plecostomus commersonni (Valenciennes, 1840) Osteichthyes - Loricariidae: desenvolvimento dos ovócitos e escala de maturidade. Revista Brasileira de Biologia, 42(1): 71-77.

Alvarez, J. 1946. Revisión del genero Anoptichthys con description de una especia nueva (Pises, Characidae). Anales de la Escuela Nacional de Ciencias Biológicas de México, 4: 263-282.

Azevedo, P. 1938. O cascudo dos açudes nordestinos "Plecostomus plecostomus”. Arquivos do Instituto de Biologia, 9: 211-224.

Balon, E. K. 1975. Terminology of intervals in fish development. Journal of the Fisheries Research Board of Canada, 32(9): 16631679.

Balon, E. K. 1981. Additions and amendments to the classification of reproductive styles in fishes. Environmental Biology of Fishes, 6: 377-389.

Balon, E. K. 1990. Epigenesis of an epigeneticist: the development of some alternative concepts on the early ontogeny and evolution of fishes. Guelph Ichthyology Reviews, 1: 1-42.

Berti, R., J. P. Durand, S. Becchi, R. Brizzi, N. Keller \& G. Ruffat. 2001. Eye degeneration in the blind cave-dwelling fish Phreatichthys andruzzii. Canadian Journal of Zoology, 79: 1278-1285.

Besharse, J. C. \& R. A. Brandon. 1974. Size and growth of the eyes of the troglobitic salamander Typhlotriton spelaeus. International Journal of Speleology, 6: 255-264.

Bessa, E. \& E. Trajano. 2002. Light reaction and cryptobiotic habits in armoured catfishes, genus Ancistrus, from caves in Central and Northwest Brazil (Siluriformes: Loricariidae). Mémoires de Biospéologie, 28: 29-37.

Bichuette, M. E. \& E. Trajano. 2003. Epigean and subterranean ichthyofauna from São Domingos karst area, Upper Tocantins river basin, Central Brazil. Journal of Fish Biology, 63: 1100-1121.

Bichuette, M. E. \& E. Trajano. 2005. A new cave species of Rhamdia (Siluriformes: Heptapteridae) from Serra do Ramalho, northeastern Brazil, with notes on ecology and behavior. Neotropical Ichthyology, 3(4): 587-595.

Blumer, L. S. 1982. A bibliography and categorization of bony fishes exhibiting parental care. Zoological Journal of the Linnean Society, 76: 1-22.

Brandon, R. A. 1971. Correlation of seasonal abundance with feeding and reproductive activity in the grotto salamander (Typhlotriton sepelaeus). American Midland Naturalist, 86(1): 93-100.

Breder, C. M. Jr. \& D. E. Rosen. 1966. Modes of reproduction in fishes. Garden City, New York, Natural History Press, 941p.

Buck, S. 1994. História natural de uma comunidade de cascudos (Loricariidae) na mata atlântica: habitat, atividade e alimentação. Unpublished MSc. Dissertation. Universidade Estadual Paulista, Rio Claro, SP, 64p.

Crawford, S. S. \& E. K. Balon. 1996. Cause and effect of parental care in fishes. Advances in the Study of Behavior, 25: 53-107.

Cruz, A. L. \& F. Langeani. 2000. Comportamento reprodutivo do cascudo Liposarcus anisitsi (Eigenmann \& Kennedy, 1903) (Ostariophysi, Loricariidae, Hypostominae) em cativeiro. Comunicações do Museu de Ciências e Tecnologia da PUCRS, Série Zoologia, 3: 109-115.
Culver, D. C. 1982. Cave life: evolution and ecology. Cambridge, Harvard University Press, 189p.

Durand, J. P. 1973. Développement et involution oculaire de Proteus anguinus Laurenti urodele cavernicole. Annales de Spéléologie, 28: 193-208.

Durand, J. P. 1976. Ocular development and involution in the European cave salamander Proteus anguinus Laurenti. Biological Bulletin, 151: 450-466.

Durand, J. P. 1979. Aspects ultrastructuraux des mécanismes de la rudimentation rétinienne chez I'Anoptichthys adulte, forme cavernicole aveugle de I'Astyanax mexicanus (Characidae: Pisces). Canadian Journal of Zoology, 57: 196-205.

Durand, J. P. 1998. Degenerescence spontanee des yeux du poisson cavernicole Lucifuga subterraneus Poey, 1861 (Teleostei: Ophidioidei). Mémoires de Biospéologie, 25: 139-143.

Durand, J. P., N. Keller, G. Renard, R. Thorn \& Y. Pouliquen. 1993. Residual cornea and degenarate eye of the cryptophthalmic Typhlotriton spelaeus. Cornea, 12(5): 437-447.

Eigenmann, C. H. 1909. The Cuban blind fishes. Pp. 185-207. In: Cave Vertebrates of America: a study in degenerative evolution. Publication Carnegie Institution of Washington, 104: 1-241.

Ekström, J. 2006. Planet catfish. Breeding Peckoltia vittata. Available from:http://www.planetcatfish.com/shanesworld/ shanesworld.php?article_id=257 (14 November 2006).

Fish-Miller, S. 2003. Subfamily Ancistrinae (Armored catfishes). Pp. 373-400. In: R. E. Reis, S. O. Kullander \& C. J. Ferraris Jr. (Eds.). Check list of the freshwater fishes of South and Central America. Porto Alegre, Edipucrs, 735p.

Garcia-Pinto, L., G. Quinones-Gonzales \& G. Friso. 1984. Biologia reproductiva de Hypostomus watwata (Osteichthyes: Loricariidae), armadillo pintado del Lago de Maracaibo. Boletin Técnico, 3: 21.

Geerinckx, T., Y. Verhaegen \& D. Adriaens. 2008. Ontogenetic allometries and shape changes in the suckermouth armoured catfish Ancistrus cf. triradiatus Eigenmann (Loricariidae, Siluriformes), related to suckermouth attachment and yolk-sac size. Journal of Fish Biology, 72: 803-814.

Hordes, S. S. 1945. Loricaria macrops, a rare catfish, breeds. The Aquarium, 13: 181.

Jeffery, W. R. 2005. Adaptive Evolution of Eye Degeneration in the Mexican Blind Cavefish. Journal of Heredity, 96(3): 185-196.

Jeffery, W. R. \& D. P. Martasian. 1998. Evolution of eye regression in the cavefish Astyanax: apoptosis and the Pax-6 gene. American Zoologist, 38(4): 685-696.

Lane, H. H. 1903. The ovarin structures of the viviparous blind fishes, Lucifuga end Stygicola. Biological Bulletin, 6(1): 38-54.

Langecker, T. L., H. Schmale \& H. Wilkens. 1993. Transcription of the opsin gene in degenerate eyes of cave-dwelling Astyanax fasciatus (Teleostei, Characidae) and of its conspecific epigean ancestor during early ontogeny. Cell Tissue Research, 273: 183-192.

Lopez-Rojas, H. \& A. Machado-Allison. 1975. Algunos aspectos del desarollo y crecimiento de Loricaria laticeps (Ostariophysi, Siluriformes, Loricariidae). Acta Biologica Venezuelica, 9(1): 51-76.

Machado-Allison, A. \& H. Lopez Rojas. 1975. Etapas del desarrollo de Loricariichthys typus (Bleeker) 1864 (Osteichthyes: Siluriformes: Loricariidae). Acta Biologica Venezuelica, 9: 93-119.

Marcucci, K. M. I., M. L. Orsi \& O. A. Shibatta. 2005. Abundância e aspectos reprodutivos de Loricariichthys platymetopon (Siluriformes: Loricariidae) em quatro trechos da represa de Capivara, médio rio Paranapanema. Iheringia, Série Zoologia, 95(2): 197-203. 
Mattox, G. M. T., M. E. Bichuette, S. Secutti \& E. Trajano. 2008. Surface and subterranean ichthyofauna in the Serra do Ramalho karst area, northeastern Brazil, with updated lists of Brazilian troglobitic and troglophilic fishes. Biota Neotropica, 8(4). Available in http://www.biotaneotropica.org.br/v8n4/pt/ abstract?inventory+bn00708042008.

Mazzoni, R. \& E. P. Caramaschi. 1995. Size structure, sex ratio and onset of sexual maturity of two species of Hypostomus. Journal of Fish Biology, 47: 841-849.

Mazzoni, R. \& E. P. Caramaschi. 1997. Observations on the reproductive biology of female Hypostomus lutkeni Lacèpéde, 1803. Ecology of Freshwater Fish, 6: 53-56.

Mendes, L. F. 1995. Observations on the ecology and behavior of a new species of troglobitic catfish from northeasten Brazil (Siluriformes: Pimelodidae). Mémoires de Biospéologie, 22: 99-101.

Moodie, G. E. E. \& M. E. Power. 1982. The reproductive biology of an armoured catfish Loricaria uracantha, from central America. Environmental Biology of Fishes, 7(2): 143-148.

Parzefall, J. 1993. Behavioral ecology of cave-dwelling fishes. Pp. 573-606. In: Pitcher, T. J. (Ed.). Behavior of Teleost Fishes. London, Chapmam \& Hall, 715p.

Peters, N. \& G. Peters. 1973. Problemes genetiques de l' evolution regressive des cavernicoles. Pp. 187-201. In: Schroeder, L. H. (Eds.). Genetics and Mutagenesis is Fish. New York, SpringerVerlag.

Pinna, M. C. C. 1998. Phylogenetic relationships of Neotropical Siluriformes: Historical overview and synthesis of hypotheses. Pp. 279-330. In: Malabarba, L. R., R. E. Reis, R. P. Vari, Z. M. Lucena \& C. A. Lucena (Eds.). Phylogeny and classification of Neotropical fishes. Porto Alegre, Edipucrs, 603p.

Poulson, T. L. 1963. Cave adaptation in Amblyopsid fishes. American Midland Naturalist, 70(2): 257-290.

Poulson, T. L. \& K. H. Lavoie. 2000. The trophic basis of subsurface ecosystems. Pp. 231-249. In: Wilkens, H., D. C. Culver \& W. F. Humphreys (Eds.). Ecosystems of the World 30. Subterranean Ecosystems. Amsterdan, Elsevier.

Poulson, T. L. \& W. B. White. 1969. The Cave Environment. Science, 165(3897): 971-985.

Protas, M. E., C. Hersey, D. Kochanek, Y. Zhou, H. Wilkens, W. R. Jeffery, L. Zon, R. Borowsky \& C. J. Tabin. 2006. Genetic analysis of cavefish reveals molecular convergence in the evolution albinism. Nature Genetics, 38(1): 107-111.

Reis, R. E. 1987. Ancistrus cryptophthalmus sp. n., a blind mailed catfish from the Tocantins River basin, Brazil (Pisces, Siluriformes, Loricariidae). Revue Française d'Aquariologie, 14: 81-84.

Reis, R. E., S. O. Kullander \& C. J. Ferraris Jr. 2003. Check List of the Freshwater Fishes of South and Central America. Porto Alegre, Edipucrs, 729p.

Reis, R. E., E. Trajano \& E. Hingst-Zaher. 2006. Shape variation in surface and cave populations of the armoured catfish Ancistrus (Siluriformes: Loricariidae) from the São Domingos karst area, Upper Tocantins River, Brazil. Journal of Fish Biology, 68: 414-429.

Riehl, R. \& R. A. Patzner. 1991. Breeding, egg structure and larval morphlogy of the catfish Sturisoma aureum (Steindachner) (Teleostei: Loricariidae). Journal of Aquariculture Aquatic Sciences, 6: 1-6.

Sato, Y., N. Fenerich-Verani, J. R. Verani, H. P. Godinho \& E. V. Sampaio. 1998. Induced reproduction and reproductive characteristics of Rhinelepis aspera Agassiz, 1829 (Osteichthyes, Siluriformes, Loricariidae). Brazilian Archives of Biology and Technology, 41(3): 309-314.
Seidel, I. 1996. New information on the zebra pleco, Hypancistrus zebra. Tropical Fish Hobbyist, 44(5).

Seidel, I. 1998. Planet catfish. Ancistrinae Ineternet Lecture. Available from: http://www.planetcatfish.com/shanesworld/ shanesworld.php?article_id=270 (14 November 2006).

Taylor, J. N. 1983. Field observations on the reproductive ecology of three species of armored catfishes (Loricariidae: Loricariinae) in Paraguay. Copeia, 1983(1): 257-259.

Thinès, G. 1960. Sensory degeneration and survival in cave fishes. Symposium of the Zoology Society of London, 3: 39-54.

Torrens, R. 2006. Planet catfish. A chance spawning of Chaetostoma. Available from: http://www.planetcatfish.com/shanesworld/ shanesworld.php?article_id=242 (14 November 2006).

Trajano, E. 1991. Populational ecology of Pimelodella kronei, troglobitic catfish from southeastern Brazil (Siluriformes: Pimelodidae). Environmental Biology of Fishes, 30: 407-421.

Trajano, E. 1997a. Food and reproduction of Trichomycterus itacarambiensis, cave catfish from south-eastern Brazil. Journal of Fish Biology, 51: 53-63.

Trajano, E. 1997b. Population ecology of Trichomycterus itacarambiensis, a cave catfish from eastern Brazil (Siluriformes: Trichomycteridae). Environmental Biology of Fishes, 50: 357-369.

Trajano, E. 2001. Habitat and population data of troglobitic armoured cave catfish, Ancistrus cryptophthalmus Reis 1987, from central Brazil (Siluriformes: Loricariidae). Environmental Biology of Fishes, 62: 195-200.

Trajano, E. \& M. E. Bichuette. 2007. Population ecology of cave armoured catfish, Ancistrus cryptophthalmus Reis, 1987, from Central Brazil (Siluriformes: Loricariidae). Ecology of Freshwater Fish, 16: 105-115.

Trajano, E., R. E. Reis \& M. E. Bichuette. 2004. Pimelodella spelaea, a new cave catfish from Central Brazil, with data on ecology and evolutionary considerations (Siluriformes: Heptapteridae). Copeia, 2004(2): 315-325.

Trajano, E. \& A. M. Souza. 1994. The behavior of Ancistrus cryptophthalmus, an armoured blind catfish from caves of Central Brazil, with notes on syntopic Trichomycterus sp. (Siluriformes, Loricariidae, Trichomycteridae). Mémoires de Biospéologie, 21: 151-159.

Vandel, A., J. P. Durand \& M. Bouillon. 1969. Observations sur le développment du Protées. Laboratoire Souterrain du C.N.R.S. Actes IV e CIS, 4-5: 263-267.

Volpato, G. L. \& M. O. Fernandes. 1994. Social control of growth in fish. Brazilian Journal of Medical and Biological Research, 27: 797-810.

Watanabe, K. 1994. Mating behavior and larval development of Pseudobagrus ichikawai (Siluriformes: Bagridae). Japanese Journal of Ichthyology, 41: 243-251.

Wilkens, H. 1987. Genetic analysis of evolutionary processes. International Journal of Speleology, 16: 33-58.

Wilkens, H. 1988. Evolution and genetics of epigean and cave Astyanax fasciatus (Characidae: Pisces). Evolutionary Biology, 23: 271-367.

Wilkens, H. 2001. Convergent adaptations to cave life in the Rhamdia latucauda catfish group (Pimelodidae: Teleostei). Environmental Biology of Fishes, 62: 251-261.

Winemiller, K. O. 1989. Patterns of variation in life history among South American fishes in seasonal environments. Oecologia, 81: 225-241.

Accepted August 4, 2009 Published September 30, 2009 